Rapid Communications

\title{
Colorimetric Recognition of Different Enzymology-concerning Transition Metals Based on a Hybrid Cluster Complex
}

\author{
Shun-Hua LI, Wen-Tao Yuan, Hong Zheng, and Jin-Gou XU ${ }^{\dagger}$ \\ The Key Laboratory of Analytical Science of MOE and Department of Chemistry, Xiamen University, \\ Xiamen 361005, P. R. China
}

\begin{abstract}
A hybrid cluster complex, formed by chelating a chromogenic ligand to a $[2 \mathrm{Fe}-2 \mathrm{~S}]$ cluster, sensitively exhibited differential colorimetric responses towards $\mathrm{Hg}^{2+}, \mathrm{Cd}^{2+}, \mathrm{Cr}^{3+}, \mathrm{Pb}^{2+}, \mathrm{Sn}^{2+}, \mathrm{Cu}^{2+}, \mathrm{Zn}^{2+}, \mathrm{Fe}^{3+}$ and $\mathrm{Co}^{2+}$ in water at physiological $\mathrm{pH}$. Speciation of some of these metal elements, such as $\mathrm{Cr}(\mathrm{III})$ and $\mathrm{Sn}(\mathrm{IV})$, was also studied by UV/Vis absorption.
\end{abstract}

(Received May 26, 2004; Accepted June 7, 2004)

We have recently developed a $[2 \mathrm{Fe}-2 \mathrm{~S}]$ cluster-containing hybrid complex as a multi-functional artificial enzyme, acting as both horseradish peroxidase and dihydroxy acid dehydratase. ${ }^{1}$ It has been learned that the structure of the $[2 \mathrm{Fe}-2 \mathrm{~S}]$ cluster can be changed by binding different metal atoms to its di-sulfur anions, ${ }^{2}$ which can be taken advantage of as a differential receptor for different transition metals. Because iron-sulfur clusters are prosthetic groups commonly found in proteins that participate in oxidation-reduction reactions and catalysis, ${ }^{3,4}$ the responses of the $[2 \mathrm{Fe}-2 \mathrm{~S}]$ cluster-containing hybrid complex towards different transition metals may reflect the different enzymological effects that they introduce in the concerned biological processes. Herein, we have developed another chromogenic $[2 \mathrm{Fe}-2 \mathrm{~S}]$ cluster-containing hybrid complex, which exhibited differential optical responses towards $\mathrm{Hg}^{2+}$, $\mathrm{Cd}^{2+}, \mathrm{Cr}^{3+}, \mathrm{Pb}^{2+}, \mathrm{Sn}^{2+}, \mathrm{Cu}^{2+}, \mathrm{Zn}^{2+}, \mathrm{Fe}^{3+}$ and $\mathrm{Co}^{2+}$ in water at physiological $\mathrm{pH}$. Speciation of some of these metal elements, such as $\mathrm{Cr}(\mathrm{III})$ and $\mathrm{Sn}(\mathrm{IV})$, could also be done by a UV/Vis absorption study.

For assembling a molecular probe, a new kind of complex, $\mathrm{Na}_{5}\left[(\mu-\mathrm{S})_{2} \mathrm{Fe}_{2}\right]$ HQSAC (Scheme 1), was adopted, which composes a $[2 \mathrm{Fe}-2 \mathrm{~S}]$ cluster center and a conformation-labile azo ligand, 2-[(8-hydroxy-5-sulfo-7-quinoline)azo]-1,8dihydroxy-3,6-naphthalene disulfonic acid (HQSAC). ${ }^{5}$ The preparation of $\mathrm{Na}_{5}\left[(\mu-\mathrm{S})_{2} \mathrm{Fe}_{2}\right] \mathrm{HQSAC} \cdot 6 \mathrm{H}_{2} \mathrm{O}$ was based on the

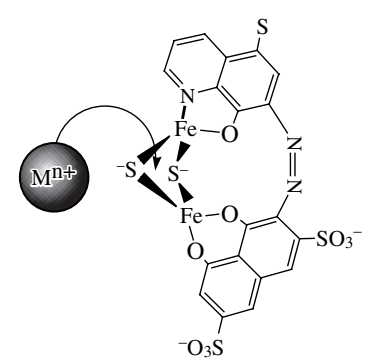

Scheme 1 Chemical structure and sensing principle of $\left[(\mu-S)_{2} \mathrm{Fe}_{2}\right] \mathrm{HQSAC}$.

$\dagger$ To whom correspondence should be addressed.

E-mail: jgxu@xmu.edu.cn high reactivity of NO groups of Roussin's red salt, which were proved to be ready for release by photodecomposition (313 $546 \mathrm{~nm}$ ) or displacement due to external chelants. ${ }^{6}$ Roussin's red sodium salt, $\mathrm{Na}_{5}\left[(\mu-\mathrm{S})_{2} \mathrm{Fe}_{2}(\mathrm{NO})_{4}\right] \cdot 8 \mathrm{H}_{2} \mathrm{O},{ }^{2,7}$ and $\mathrm{HQSAC}$ were dissolved in aqueous solution at $\mathrm{pH} 5.0$ - 8.0 with a molar ratio of $1: 1$. The red mixture solution was stirred at $60^{\circ} \mathrm{C}$ in a water bath, and a disgusting gas was released. After stirring for $6.0 \mathrm{~h}$, the solution was dried by rotary evaporation. After the dried solid was extracted with methanol, the methanol solution was dried under vacuum to give $\mathrm{Na}_{5}\left[(\mu-\mathrm{S})_{2} \mathrm{Fe}_{2}\right] \mathrm{HQSAC} \cdot 6 \mathrm{H}_{2} \mathrm{O}$ as a red solid. The obtained product was stored under a nitrogen atmosphere in a desiccator, where it was found to be stable for one month. Anal. Calcd for $\mathrm{Na}_{5}\left[(\mu-\mathrm{S})_{2} \mathrm{Fe}_{2}\right]-$ HQSAC. $6 \mathrm{H}_{2} \mathrm{O}, \mathrm{C}_{19} \mathrm{H}_{19} \mathrm{Fe}_{2} \mathrm{~N}_{3} \mathrm{Na}_{5} \mathrm{O}_{18} \mathrm{~S}_{5}: \mathrm{C}, 23.67 ; \mathrm{H}, 1.99 ; \mathrm{N}$, 4.38; S, 16.63. Found: C, 23.61; H, 2.05; N, 4.40; S, 16.53 . The number of crystal waters was further determined by thermogravimetry. The biological mass spectrum displayed the characteristic peak at $\mathrm{m} / z, 742(\mathrm{M}+1)$, the FT-IR spectrum of the solid in $\mathrm{KBr}$ displayed no $v_{\mathrm{NO}}$ bands at around 1800 (w), 1715 (s) or 1675 (s) $\mathrm{cm}^{-1}$, which were usually found in the IR spectra of Roussin's red or Roussin's black salts. ${ }^{6}$

The UV/Vis absorption responses of $\mathrm{Na}_{5}\left[(\mu-\mathrm{S})_{2} \mathrm{Fe}_{2}\right] \mathrm{HQSAC}$ sensing solution towards different metal ions (added with

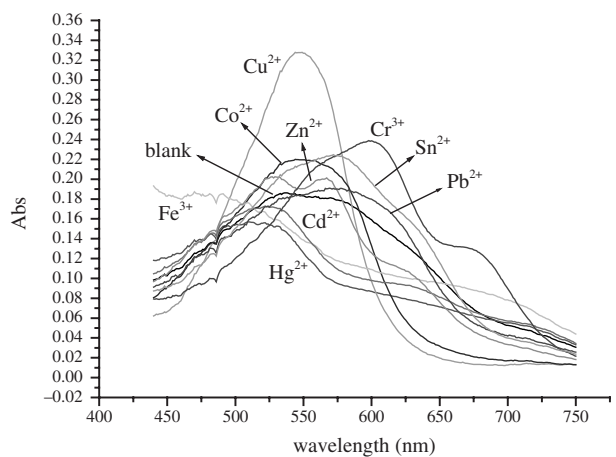

Fig. 1 Absorption responses of $\mathrm{Na}_{5}\left[(\mu-\mathrm{S})_{2} \mathrm{Fe}_{2}\right] \mathrm{HQSAC}\left(3.40 \times 10^{-5}\right.$ $\mathrm{M}$; buffered at pH 5.0 with $0.02 \mathrm{M} \mathrm{NaAc}-\mathrm{HAc}$ solution) towards different transition metal ions $\left(1.0 \times 10^{-4} \mathrm{M}\right.$, chloride as the counterions). 

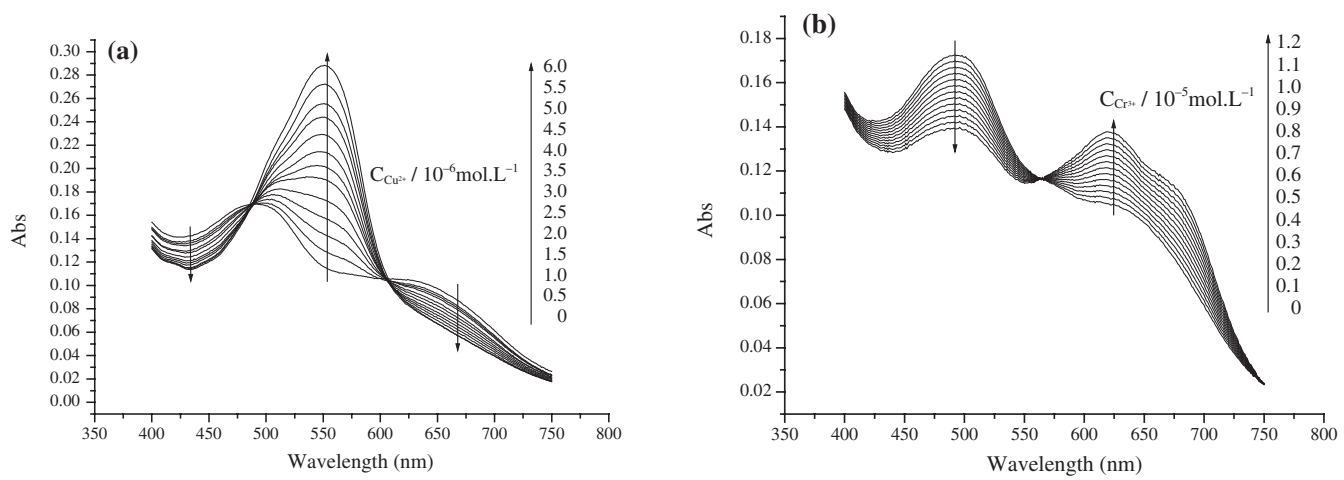

Fig. 2 UV/Vis spectra of $\mathrm{Na}_{5}\left[(\mu-\mathrm{S})_{2} \mathrm{Fe}_{2}\right] \mathrm{HQSAC}$ solutions titrated with a standard solution of metal ions $\left(\mathrm{a}, \mathrm{Cu}^{2+} ; \mathrm{b}, \mathrm{Cr}^{3+}\right)$. The final concentration of $\left[(\mu-\mathrm{S})_{2} \mathrm{Fe}_{2}\right] \mathrm{HQSAC}$ is $2.50 \times 10^{-5} \mathrm{M}$. Test solutions were buffered at $\mathrm{pH} 7.40$ with a $0.05 \mathrm{M}$ Tris- $\mathrm{HCl}$ solution.
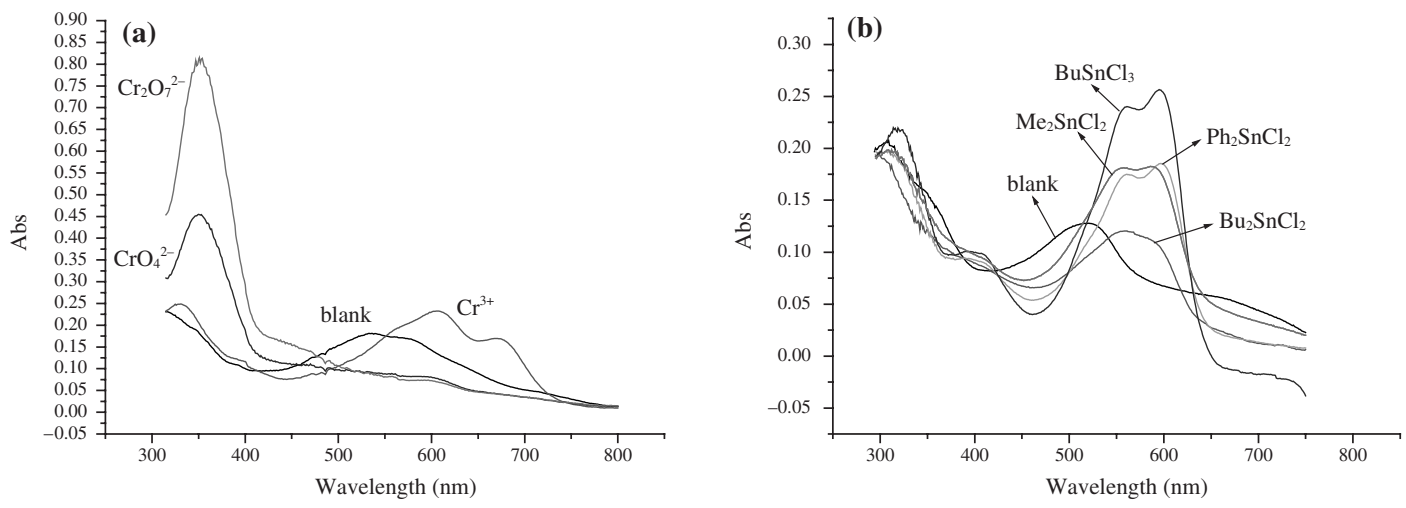

Fig. 3 Speciation of $\mathrm{Cr}$ (a) in a $\mathrm{pH} 7.4$ aqueous Tris- $\mathrm{HCl}$ buffer solution (final concentration: $\left.C_{[(\mu-S) \mathrm{Fe}] \mathrm{HQSAC}}=3.40 \times 10^{-5} \mathrm{M} ; \mathrm{CCr}=2.00 \times 10^{-4} \mathrm{M}\right)$ and $\mathrm{Sn}(\mathrm{IV})(\mathrm{b})$ in $85.0 \%$ ethanol aqueous solution (final concentration: $C_{\left[\left(\mu-S_{2}\right) \mathrm{Fe}_{2}\right] \mathrm{HQSAC}}=3.10 \times 10^{-5} \mathrm{M} ; C_{\mathrm{Sn}}=8.65 \times 10^{-4} \mathrm{M}$ ).

chlorides of metals) in aqueous solution at $\mathrm{pH} 5.0$ are shown in Fig. 1; the tested ions included $\mathrm{K}^{+}, \mathrm{Na}^{+}, \mathrm{Li}^{+}, \mathrm{Ca}^{2+}, \mathrm{Ba}^{2+}, \mathrm{Al}^{3+}$, $\mathrm{Mg}^{2+}, \mathrm{Mn}^{2+}, \mathrm{Ni}^{2+}, \mathrm{Hg}^{2+}, \mathrm{Cd}^{2+}, \mathrm{Cr}^{3+}, \mathrm{Pb}^{2+}, \mathrm{Sn}^{2+}, \mathrm{Cu}^{2+}, \mathrm{Zn}^{2+}, \mathrm{Fe}^{3+}$ and $\mathrm{Co}^{2+}$. Only a relatively low $\mathrm{pH}$ was used in order to ensure that the metal ions are not affected by $\mathrm{OH}^{-}$anions in water. Figure 1 illustrates that obvious color shifts were induced by the addition of $\mathrm{Hg}^{2+}, \mathrm{Cd}^{2+}, \mathrm{Cr}^{3+}, \mathrm{Pb}^{2+}, \mathrm{Sn}^{2+}, \mathrm{Cu}^{2+}, \mathrm{Zn}^{2+}, \mathrm{Fe}^{3+}$ or $\mathrm{Co}^{2+}$. This phenomenon occurred over a wide $\mathrm{pH}$ range from 4.5 to 9.0 without any distinct changes in the absorption spectra. It is interesting that all of the color-responding ions are known to be toxic or to be essential to some physiological processes. Since iron-sulfur clusters are often involved in these processes, these phenomena, which reflect the structural changes of the clusters, are useful for toxicological evaluations of transition-metal ions. Further study also indicated that different species formed by different molar ratios of metal/ $\left[(\mu-\mathrm{S})_{2} \mathrm{Fe}_{2}\right] \mathrm{HQSAC}$ with the same metal element induced different UV/Vis absorption spectra. This diversity of the interaction modes between metal and $\left[(\mu-S)_{2} \mathrm{Fe}_{2}\right] \mathrm{HQSAC}$ made it difficult to measure the coordination constants of different metal ions binding to $\left[(\mu-\mathrm{S})_{2} \mathrm{Fe}_{2}\right] \mathrm{HQSAC}$. However, in a biological sense, this is true to the nature of biological systems.

The coordination constants of different metal ions binding to $\left[(\mu-\mathrm{S})_{2} \mathrm{Fe}_{2}\right] \mathrm{HQSAC}$ are expected to be high due to the known highly favorable interaction between these metal ions and sulfur anions. This was proved by the UV/Vis spectra gained by titrating a $\mathrm{Na}_{5}\left[(\mu-\mathrm{S})_{2} \mathrm{Fe}_{2}\right] \mathrm{HQSAC}$ solution with standard solutions of transition-metal ions, such as $\mathrm{Cu}^{2+}$ and $\mathrm{Cr}^{3+}$ (Fig. 2). There were good linearities between the characteristic absorbances and the concentrations of the corresponding metal ions, which indicated that metal ions had been completely "captured", even at low concentration levels. That is, a quantitative determination of these transition metal ions by spectrophotometry is ready to be performed at considerably low concentration levels. For example, the concentrations of $\mathrm{Cu}^{2+}$ and $\mathrm{Cr}^{3+}$ can be easily measured when their molar concentrations are below one third and half of that of $\left[(\mu-S)_{2} \mathrm{Fe}_{2}\right] \mathrm{HQSAC}$, respectively, a concentration condition that ensures the target metal ions are bound to the $[2 \mathrm{Fe}-2 \mathrm{~S}]$ centers at an identical molar ratio.

Some applications of the developed sensor to speciation recognition of transition metals were also studied. Figure $3 \mathrm{a}$ shows the spectral responses of $\mathrm{Na}_{5}\left[(\mu-\mathrm{S})_{2} \mathrm{Fe}_{2}\right] \mathrm{HQSAC}$ towards $\mathrm{K}_{2} \mathrm{Cr}_{2} \mathrm{O}_{7}, \mathrm{~K}_{2} \mathrm{CrO}_{4}$ and $\mathrm{CrCl}_{3}$ in water. $\mathrm{Cr}(\mathrm{III})\left(\lambda_{\max }=354 \mathrm{~nm}\right)$ and $\operatorname{Cr}(\mathrm{VI})\left(\lambda_{\max }=606,671 \mathrm{~nm}\right)$ were clearly distinguished in the UV/Vis spectra. Obviously, HQSAC had been oxidated by $\mathrm{Cr}(\mathrm{VI})$ anions. It is interesting that the new species induced by the reaction with $\mathrm{Cr}_{2} \mathrm{O}_{7}^{2-}\left(\varepsilon_{354 \mathrm{~nm}}=2.42 \times 10^{4} \mathrm{~cm}^{-1} \mathrm{~mol}^{-1} \mathrm{~L}\right)$ exhibited a near twofold molar absorption coefficient compared to $\mathrm{CrO}_{4}{ }^{2-}\left(\varepsilon_{354 \mathrm{~nm}}=1.33 \times 10^{4} \mathrm{~cm}^{-1} \mathrm{~mol}^{-1} \mathrm{~L}\right)$. Thus, $\mathrm{Cr}$ (III) and $\mathrm{Cr}(\mathrm{VI})$ can be well qualitatively and quantitatively analyzed using this sensing system. Developing optical molecular chemosensors for speciation of organic transition metal compounds is still a challenging task. Since Roussin's red 
Table 1 Absorption maximum wavelength and molar absorption coefficient of products formed by $\left[(\mu-\mathrm{S})_{2} \mathrm{Fe}_{2}\right] \mathrm{HQSAC}$ and different transition metal ions according to Fig. 1

\begin{tabular}{|c|c|c|c|c|c|c|}
\hline & Blank $\mathrm{Cr}^{3+} \mathrm{Sn}^{2+}$ & $\mathrm{Co}^{2+} \mathrm{Pb}^{2+}$ & $\mathrm{Cu}^{2+}$ & $\mathrm{Zn}^{2+}$ & $\mathrm{Cd}^{2+}$ & $\mathrm{Hg}^{2+}$ \\
\hline $\begin{array}{l}\lambda_{\max } \\
(\mathrm{nm})\end{array}$ & $\begin{array}{lll}532 & 620 & 573\end{array}$ & $577 \quad 571$ & 547 & $\begin{array}{l}5571 \mathrm{a}, \\
5276 \mathrm{~b}\end{array}$ & 529 & \\
\hline $\begin{array}{c}\mathcal{E} \\
\left(\mathrm{cm}^{-1} \mathrm{~mol}^{-1} \mathrm{~L}\right)\end{array}$ & 500068387438 & 68745247 & 9550 & $\begin{array}{l}528 \mathrm{a} \\
565 \mathrm{~b}\end{array}$ & 5103 & 4282 \\
\hline
\end{tabular}

sodium salt has been proved to react efficiently with a wide range of organic halides, such as $\mathrm{R}_{3} \mathrm{SnX}(\mathrm{R}=\mathrm{Ph}, \mathrm{Me}), \mathrm{Ph}_{3} \mathrm{PbBr}$ and $\mathrm{RHgX}(\mathrm{R}=\mathrm{Ph}, \mathrm{Me})^{2}$, some different organic $\mathrm{Sn}(\mathrm{IV})$ containing compounds were also tested in a mixed ethanol/water solvent. The result showed that these different species of $\mathrm{Sn}(\mathrm{IV})$ induced different new UV/Vis spectra of the sensing solution (Fig. 3b). We think this will lead to its further important applications in the speciation analysis and toxicological evaluation of $\mathrm{Hg}(\mathrm{II}), \mathrm{Sn}$ (IV), $\mathrm{Pb}$ (II) and $\mathrm{Cd}(\mathrm{II})$. Compared to the traditional chromatogram-based method, this sensing system offers the possibility of performing in-situ measurements, since freely mobile chromogenic sensing molecules can be easily employed in microscopical analysis.

\section{Acknowledgements}

This work was supported by the National Natural Science Foundation of China (No. 20275033).

\section{References}

1. W. T. Yuan, S. H. Li, H. Zheng, and J. G. Xu, Anal. Sci., 2004, 20, 589.

2. D. Seyferth and M. K. Gallagher, Organometallics, 1986, 5,539 .

3. H. Beinert, R. H. Holm, and E. Münck, Science, 1997, 277, 653.

4. D. C. Rees and J. B. Howard, Science, 2003, 300, 929.

5. Y. Yan, Z. Q. Ji, and J. F. Huang, Chin. J. Anal. Chem., $1993,21,1$

6. J. Bourassa, W. DeGraff, S. Kudo, D. A. Wink, J. B. Mitchell, and P. C. Ford, J. Am. Chem. Soc., 1997, 119, 2853.

7. F. Seel, in "Handbook of Preparative Inorganic Chemistry", ed. G. Brauer, 2nd ed., 1965, Vol. 2, Academic Press, New York, 1763. 